\title{
Rare cause of paediatric wrist pain unmasked by minor trauma
}

\author{
Fahim Patel, Arani V Sridhar
}

Paediatric Rheumatology, University Hospitals of Leicester NHS Trust, Leicester, UK

Correspondence to Dr Fahim Patel;

fahim.patel@nhs.net

Accepted 8 July 2021

\section{DESCRIPTION}

A 10-year-old girl was referred to paediatric rheumatology with a 6-month history of a painful, swollen left wrist associated with functional limitation and disturbed sleep. She initially had a minor fall, and X-rays at the time showed no bony abnormalities (figure 1). Blood tests were normal, including inflammatory markers and autoimmune screen. Wrist MRI showed significant synovial thickening and avascular necrosis of the left lunate (figure 2). She received non-steroidal antiinflammatories and physiotherapy, but a year later, continues to have chronic regional pain with allodynia and hyperalgesia.

Kienböck disease, an eponym for avascular necrosis of the lunate bone, is of unknown aetiology and incidence. ${ }^{1}$ The proposed trigger is trauma in those with a susceptibility due to natural skeletal and vascular variations. ${ }^{2}$ It is the most common cause of adult aseptic osteonecrosis of the upper extremity, usually in dominant hands of men aged $20-40$ years. ${ }^{3}$ Paediatric Kienböck is rare, presenting as pain, stiffness, swelling and reduced power, often after an innocuous fall. Diagnostically, this is challenging because the mechanism suggests

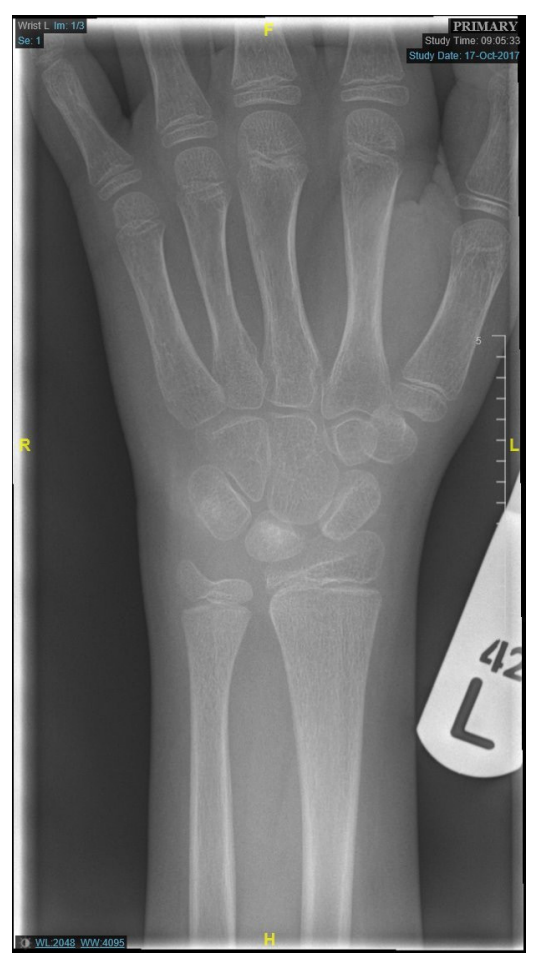

Figure 1 A plain radiograph of the left wrist taken shortly after the injury shows no visible alterations.

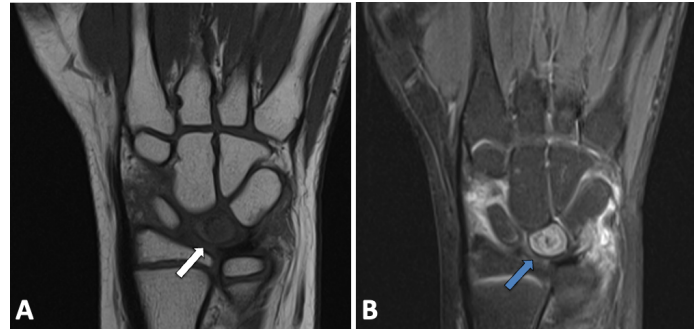

Figure 2 Coronal T1-weighted (A) and coronal T2weighted fat-supressed (B) MRI of the left wrist. The lunate bone has low T1 signal (white arrow) and high T2 signal (blue arrow) due to bone marrow oedema and bony changes associated with avascular necrosis. The synovium exhibits the same pattern of signal change due to thickening and reactive inflammatory changes. Negative ulnar variance is also present; there is a significant association with Kienböck disease.

\section{Patient's perspective}

Our patient received non-steroidal antiinflammatories and physiotherapy, but a year later, continued to have chronic regional pain with allodynia and hyperalgesia. Despite this, she remains upbeat and continues to live a normal childhood and has coped well with the recent increase in computer usage and typing associated with remote schooling as a consequence of school closures during the COVID-19 pandemic.

Learning points

- Kienböck disease is an eponym for avascular necrosis of the lunate bone. It is of unknown aetiology and incidence, but the proposed trigger is trauma in patients with a skeletal and vascular susceptibility. In the majority of cases (approximately $80 \%$ ), there is a significant association with negative ulnar variance.

- Kienböck disease is a rare paediatric diagnosis, but the most common cause of adult aseptic osteonecrosis of the upper extremity, usually affecting the dominant hands of men aged 20-40 years.

- Kienböck disease can develop insidiously and should, therefore, be considered in both adults and paediatric patients presenting with a chronic non-resolving or partially-resolving wrist trauma. 
a soft tissue injury whereas the chronicity mimics juvenile idiopathic arthritis.

Radiographical severity is defined by Lichtman classification and used to guide non-curative surgical or conservative management. ${ }^{4}$ This aims to relieve pressure on the lunate bone and restore perfusion. Anti-inflammatory medications are offered prior to surgical joint levelling to reduce pain, swelling and deformity. ${ }^{5}$

We emphasise that clinicians consider this rare, destructive pathology in their differential diagnosis for paediatric chronic wrist pain and swelling, especially in those presenting weeks after a seemingly innocuous hand trauma.

Acknowledgements Our 10-year-old patient and her family for kindly and bravely contributing her experiences for our learning. Dr Ahmed Sharaf (Department of Radiology, University Hospitals of Leicester) for his kind help and advice in selecting the radiological images.
Contributors FP: First author. AVS: Consultant supervisor.

Funding The authors have not declared a specific grant for this research from any funding agency in the public, commercial or not-for-profit sectors.

Competing interests None declared.

Patient consent for publication Obtained.

Provenance and peer review Not commissioned; externally peer-reviewed.

\section{REFERENCES}

1 Kienböck R. Über traumatische Malazie des Mondbeins und Ihre Folgezustände: Entartungsformen und Kompressions frakturen. Fortschr Geb Rontgenstr 1910;16:77-103.

2 Irisarri C. Aetiology of Kienbőck's Disease. J Hand Surg Am 2004;29:279-85.

3 Shayesteh Azar M, Shahab Kowsarian SA, Mohseni-Bandpe MA, Azar MS, Kowsarian SAS, et al. Kienbock's disease in a child. Iran J Med Sci 2011;36:133-5.

4 Allan CH, Joshi A, Lichtman DM. Kienbock's disease: diagnosis and treatment. J Am Acad Orthop Surg 2001;9:128-36.

5 Innes L, Strauch RJ. Systematic Review of the Treatment of Kienböck's Disease in Its Early and Late Stages. J Hand Surg Am 2010;35:713-7.

Copyright 2021 BMJ Publishing Group. All rights reserved. For permission to reuse any of this content visit

https://www.bmj.com/company/products-services/rights-and-licensing/permissions/

BMJ Case Report Fellows may re-use this article for personal use and teaching without any further permission.

Become a Fellow of BMJ Case Reports today and you can:

- Submit as many cases as you like

- Enjoy fast sympathetic peer review and rapid publication of accepted articles

- Access all the published articles

- Re-use any of the published material for personal use and teaching without further permission

Customer Service

If you have any further queries about your subscription, please contact our customer services team on +44 (0) 2071111105 or via email at support@bmj.com.

Visit casereports.bmj.com for more articles like this and to become a Fellow 